\title{
Citizenship in the Era of Blockchain-Based Virtual Nations
}

\author{
Primavera De Filippi
}

In the last decades, modern democracies have been witnessing a low rate of political participation and civic engagement with existing governmental institutions. Low voter turnout, especially with younger generations, is raising significant concerns for many representative democracies, and trust in public institutions has dropped to a point that it has become difficult for people to engage in political activity. ${ }^{1}$

Civic participation is not dead, however, it is only shifting to a new space. With the advent of internet and digital technologies, citizens of the world are coalescing into increasingly globalized social movements, ${ }^{2}$ paving the way for new forms of political engagement. ${ }^{3}$ With the blockchain, these individuals could find new ways to spontaneously organize and coordinate themselves into transnational 'cloud communities', and - as Liav Orgad suggests (chapter "Cloud Communities: The Dawn of Global Citizenship?")even acquire their own self-sovereign identity that subsists independently of any nation-state. Those, I believe, are some of the most compelling developments of blockchain technology, which I have been following closely over the past few years.

But what makes blockchain technology a powerful tool for promoting disintermediation and decentralized coordination - i.e. a trustless technol-

\footnotetext{
1 According to Pew Research, in 2016, only 19 per cent of Americans said they trust their government, among the lowest levels in the past half-century. See http://www.people-press.org/2015/11/23/beyond-distrust-how-americans-viewtheir-government/. The same is true at the international level. A GCF survey found out that 85 per cent of the respondents in eight countries believe that the UN needs to be reformed to better deal with global risks and 71 per cent support the establishment of a new supranational organization. See https://api. globalchallenges.org/static/files/ComRes.pdf

2 Cohen, R. \& R. Shirin (eds.) (2004), Global social movements. London: A\&C Black.

3 Della Porta, D., \& S. G. Tarrow (eds.) (2005), Transnational protest and global activism. Lanham (MD): Rowman \& Littlefield.
} 
$o g y$-also constitutes one of its greatest limitations, especially when it comes to political deliberation. While politics is about reaching a compromise between conflicting interests and values, blockchain technology operates via distributed consensus and an exit-based conflict resolution system. As underlined by Rainer Bauböck, relying on voluntary cloud communities as a means to govern society could significantly increase inequalities, leading to an overall loss of democratic representation and wealth redistribution.

In a sense, I agree with the diverging views of both Orgad and Bauböck. When brought to an extreme, blockchain technology could create - simultaneously - a utopian society characterized by greater individual freedom and autonomy, and a dystopian society driven by market-based incentives and self-dealing. But reality is neither black or white; it often has many different shades of grey. I see blockchain technology as neither the cure nor the curse of today's political institutions. Rather, I see it as a tool that could enable us to experiment with new governance structures and alternative political systems - in a world where there is very little room left for experimentation.

\section{Multiple shades of activism}

Digital activism is a not a recent phenomenon. Social movements increasingly leverage the power of digital technologies to coordinate themselves and communicate to a broader audience - as illustrated by the role played by social media during the Arab uprisings in 2011. ${ }^{4}$ But the internet also enabled the emergence of new communities of kinship, with a variety of online platforms (e.g Facebook, Twitter, Whatsapp) gathering people around specific interests or values, regardless of their political views. Some of these communities operate as tight social groups, providing members with a newfound sense of belonging and a collective identity. ${ }^{5}$ While they do not engage in what we usually regard as political activity, these online communities play a key role in shaping the way people organize and coordinate themselves, in ways that significantly differ from those of existing political institutions. ${ }^{6}$ Apart from the legal regime these communities operate in, they are gov-

4 Howard, P. N., A Duffy, D. Freelon, M. M. Hussain, W. Mari \& M. Maziad (2011), 'Opening closed regimes: what was the role of social media during the Arab Spring?', Project on Information Technology \& Political Islam Working Paper 2011.1, available at https://papers.ssrn.com/sol3/papers.cfm?abstract_ id $=2595096$

5 Wellman, B. \& M. Gulia (1999), 'Virtual communities as communities: Net surfers don't ride alone', in M. A. Smith \& P. Kollock (eds.), Communities in cyberspace, 167-194. London; New York: Routledge.

6 Norris, P. (2002), 'The bridging and bonding role of online communities', Politics 7 (3): 3-13. 
erned by their own systems of rules and social norms - which members voluntary abide by.

In her book, 'Social Movements and Their Technologies: Wiring Social Change', Stefania Milan illustrates the different approaches of social movements in materializing their ideas into the world. ${ }^{7}$ Insiders adopt a cooperative attitude: they recognise existing institutions as a legitimate source of power and actively engage in their game, through advocacy and traditional decision-making procedures. ${ }^{8}$ Outsiders adopt a more confrontational attitude: they reject the rules of these institutions and choose instead to exert pressure from the outside, through campaigns, protest or other form of political resistance. ${ }^{9}$ Finally, what she refers to as beyonders are a wholly different bunch. Beyonders simply refuse to engage with existing institutions: they do not want to fight them nor do they want to change them, they simply regard them as a leftover from a past era - which they are trying to render obsolete by building new systems. ${ }^{10}$ Thus, relatively to the other two groups, beyonders operate in a way that is more autonomous or independent; they do not play for or against the established political system, they just decide to ignore it or bypass it.

Is it fair to conclude that beyonders do not play a political role in society? Clearly not. By creating an alternative to existing institutions, they exert an indirect pressure forcing them to adjust themselves to maintain their position. Perhaps more so than insiders and outsiders, who operate within a given political framework, beyonders are deeply concerned with social change. Their political action is the result of a constructive reaction to the current state of affairs. They are responding to their own needs using new schemes and methodologies, leveraging the power of communities to create new institutions that will help them fulfil their missions - through what essentially amounts to a new form of political organisation.

7 Milan, S. (2013), Social movements and their technologies: Wiring social change. London: Springer, 118-136.

8 Moe, T. M. (2005), 'Power and political institutions', Perspectives on Politics 3 (2): 215-233.

9 Maloney, W. A., G. Jordan \& A. M. McLaughlin (1994), 'Interest groups and public policy: the insider/outsider model revisited', Journal of Public Policy 14 (1): 17-38.

10 Hintz, A. \& S. Milan (2011), 'User rights for the Internet age: Communications policy according to "Netizens", in R. Mansell \& M. Raboy (eds.), The handbook of global media and communication policy, 230-241. Chichester, West Sussex; Malden, MA: Wiley-Blackwell. 


\section{Beyond the blockchain}

Today, in the shadow corners of the internet, a new group of beyonders is emerging, looking at blockchain technology as a means to replace many of our traditional institutions. While most of the attention was put, initially, on Bitcoin disrupting banks and other financial operators, ${ }^{11}$ as people understood the full potential of blockchain technology, they saw it a means to implement new governance structures that could potentially replace some of our existing systems of governance. ${ }^{12}$

At the extreme end of this spectrum are those who envision the creation of new blockchain-based virtual nations, with a view to ultimately replace the nation-state. This is the case, for instance, of Bitnation: an initiative aimed at creating a new sovereign jurisdiction that operates only and exclusively in cyberspace, independently of any geographical boundaries. Founded in 2014, Bitnation describes itself as a decentralized borderless voluntary nation that anyone can join or leave as they wish: ${ }^{13}$ a transnational community of global citizens that spontaneously coordinate themselves, with no recourse to coercion.

To early internet pioneers, this might sound familiar. Already in 1996, in the 'Declaration of the Independence of Cyberspace', John Perry Barlow described the digital world as an independent space that simply could not be regulated, because - he claimed - governments did not have the right nor the capacity to exert their sovereignty over $\mathrm{it}^{14}$ (even though history has eventually taught us otherwise).

11 De Filippi, P. (2014), 'Bitcoin: a regulatory nightmare to a libertarian dream', Internet Policy Review 3 (2): 43.

12 Davidson, S., P. De Filippi \& J. Potts (2016), 'Disrupting governance: The new institutional economics of distributed ledger technology', available at SSRN: https://ssrn.com/abstract=2811995

13 According to the Bitnation website, Bitnation is a decentralized is fostering 'a peer-to-peer voluntary governance system, rather than the current "top-down", "one-size-fits-all" model, restrained by the current geographical apartheid, where your quality of life is defined by where you were arbitrarily born.' See https://bitnation.co/join-the-team/

14 'Governments of the Industrial World, you weary giants of flesh and steel, I come from Cyberspace, the new home of Mind. On behalf of the future, I ask you of the past to leave us alone. You are not welcome among us. You have no sovereignty where we gather.' Barlow, J. P. (1996), Declaration of Independence of Cyberspace. Available at http://homes.eff.org/ barlow/ Declaration-Final.html 
Barlow was essentially a beyonder - mocking the various governmental attempts at regulating the internet landscape, in ways that he considered to be ineffective in this new digital era. Similarly, Bitnation is mostly the result of a beyonders' approach to governance, trying to create a new sovereign nation that ignores the rules and procedures of existing nation-states, regarded as obsolete in this new digital world. Because it operates on a transnational and decentralized peer-to-peer network (the Ethereum blockchain), Bitnation is not under the control of any one government. Indeed, by relying on blockchain technology, Bitnation is creating a system that not only tries to escape from the hegemony of nation-states - because it has no single point of failure, or control - but also tries to compete with existing institutions and governmental systems - by providing self-sovereign identities, notarization services, property rights and company registration, dispute resolution systems, etc. which are usually associated with the functions of the public administration. The Ethereum blockchain is particularly useful in this context, because - as a public and transnational blockchain - it provides the necessary transparency, verifiability, incorruptibility and trust that one would expect from these governmental services.

'Governance in the real world is so fucked. We have to start thinking about how to build it in the virtual world' said Lawrence Lessig in an interview $^{15}$, after he resigned from the 2016 presidential campaign. While Lessig was referring to the creation of a massive multiplayer online game ${ }^{16}$ inviting players to experiment with different forms of governances, it might be worth investigating whether initiatives such as Bitnation, and other attempts at creating blockchain-based virtual nations (such as Cultu.re) or even blockchain-based virtual worlds (such as Decentraland) could actually provide a new space of experimentation, allowing people to experiment with new political systems that operate outside of any defined territory. Indeed, these initiatives - which rely on decentralised blockchain-based systems are not located in any given jurisdiction: they subsist in a transnational space, which has yet to be colonised by new governance structures and experimental political regimes.

15 “'Governance in the Real World Is So Fucked:” Lawrence Lessig Is Working on an MMO', Motherboard, 8 June 2017, available at https://motherboard. vice.com/en_us/article/neweqm/lawrence-lessig-is-working-on-an-mmogame-seed

16 'Think the government is doomed? See if you can build a better one in "Seed", Digital Trends, 8 March 2017, available at https://www.digitaltrends. com/gaming/seed-mmo-interview-democracy-lawrence-lessig/ 


\section{Blockchain-based virtual nations}

Can these blockchain-based systems support the emergence of a new framework for global citizenship (as suggested by Liav Orgad, amongst others ${ }^{17}$ ) where people pledge allegiance not to an existing government or nationstate, but to a global community that transcends national boundaries? ${ }^{18}$ Can they support a new understanding citizenship as collective identity, providing new opportunities for collective action and civic participation in a postnational world? ${ }^{19}$ As with many things today, the answer is not a simple one. The concept of blockchain-based virtual nations is interesting because it is highly controversial. It is, in fact, supported by different groups, for very different purposes.

On the one hand, the concept of a virtual nation is appealing to many libertarians, who see it as an opportunity to reduce the room for governmental intervention, by creating new ad-hoc governmental structures aimed at creating a society governed by (unregulated) market forces, and nothing else. This is the vision brought forward most prominently by Peter Thiel, who envisions the creation of a new sovereign nation on an offshore artificial island ${ }^{20}$, built 200 miles off the Californian coast. This vision is also shared by a number of crypto-libertarians, ${ }^{21}$ such as the team behind Bitnation, who believe that - since we have lost trust in our governments - we shall now

17 The notion of 'world citizen' has been endorsed by a variety of scholars, activists and social movements. See, in particular, Ulrich Beck's notion of 'cosmopolitanism' and discussions on the 'post-westphalian' international system. See Beck, U. (2003), 'Toward a new critical theory with a cosmopolitan intent', Constellations 10 (4): 453-468; Beck, U. \& N. Sznaider (2006), 'Unpacking cosmopolitanism for the social sciences: a research agenda', The British Journal of Sociology 57 (1): 1-23.

18 See also the work of Tölölyan, K. (1996), 'Rethinking diaspora(s): Stateless power in the transnational moment', Diaspora: A Journal of Transnational Studies 5 (1): 3-36; Grewal, I. (2005), Transnational America: feminisms, diasporas, neoliberalisms. Durham: Duke University Press; and Van Hear, N. (2005), New diasporas: The mass exodus, dispersal and regrouping of migrant communities. London: Routledge (on diasporas as transnational entities).

19 Sassen, S. (2002), 'Towards post-national and denationalized citizenship', in E. F. Isin \& B. S. Turner (eds.), Handbook of citizenship studies, 277-292. London: Sage.

20 'Libertarians Seek a Home on the High Seas', The New Republic, 29 May 2017, available at https://newrepublic.com/article/142381/ libertarians-seek-home-high-seas

21 May, T. C. (1994), Crypto anarchy and virtual communities. Available at http:// aom.jku.at/archiv/cmc/text/may_n01.pdf 
rely on blockchain technology to create trustless systems (i.e. systems where trust is no longer needed) with a view to support and facilitate a series of atomic peer-to-peer interactions in a seemingly stateless environment. ${ }^{22}$

On the other hand, there are people who see virtual nations as an opportunity to overcome the lack of trust in governmental institutions, through the creation of new trusted communities with a global scope. These communities can experiment with new institutional structures that operate independently from, or as a complement to existing institutions. They can support the emergence of grassroots initiatives intended to fill the gaps generated by the progressive shrinking of the welfare state $-i$.e. the provision of public services and shared infrastructure, the pursuit of the common good, and the protection of individual and collective rights. ${ }^{23}$ Blockchain technologies could provide new mechanisms of social or political coordination, allowing for transnational communities and activist groups (such as human rights defenders, internet freedoms advocates and climate change campaigners) to gather around a newfound sense of identity and organise themselves as a collective.

The idea is not to replace nation-states with new or competing forms of sovereignty, but rather to provide new means for global communities to mobilise and experiment with new ways of engaging in civic life. If political participation no longer finds its place in the context of traditional governmental structures, perhaps these virtual communities - or cloud communities, as Orgad calls them - might be able to bring civics back to life. Indeed, if citizenship refers not only to a legal status, but also to an individual's political activity and collective identity, ${ }^{24}$ we might soon witness the emergence of new global citizens, who regard these new virtual nations as polities and self-identify as their members.

This is the vision supported by initiatives like Democracy Earth and Aragon, two blockchain-based platforms providing tools for small and large organisations to operate in a globalised post nation-state world, through their own governance rules and dispute resolution systems. Without trying

22 Atzori, M. (2015), 'Blockchain technology and decentralized governance: Is the state still necessary?', available at SSRN: https://ssrn.com/ abstract=2709713 or https://doi.org/10.2139/ssrn.2709713

23 Feigenbaum, H., J. Henig \& C. Hamnett (1998), Shrinking the state: The political underpinnings of privatization. Cambridge: Cambridge University Press.

24 Dalton, R. J. (2008), 'Citizenship norms and the expansion of political participation', Political Studies 56 (1): 76-98; Eisenstadt, S. N. \& B. Giesen (1995), 'The construction of collective identity', European Journal of Sociology 36 (1): 72-102. 
to replace the role of the state as a political institution, these initiatives are exploring whether (and how) some of the functions undertaken by governmental authorities - e.g. the issuance of identity cards, recordation of vital records and maintenance of public registries, etc. - could be transposed into a blockchain-based system.

People are ideally free to decide, on a case-by-case basis, whether they want to rely on traditional institutions and governmental frameworks, or whether they would rather adopt these new experimental systems, whose values they might feel more attuned with. As a general rule, citizens cannot easily revoke their allegiance to a particular nation-state, because - as highlighted by Rainer Bauböck - the social contract described by Hobbes and Rousseau is not a negotiable contractual agreement entered into by consent (i.e. citizenship as a legal status is generally something that one does not chose and that, once acquired, cannot be easily gotten ridden of). Yet, to the extent possible, they could choose to acquire additional citizenships, becoming members of multiple communities based on affinity and consent. Insofar as they provide valuable services to their citizens, these virtual communities (or virtual nations) may be competing with one another - and potentially with nation-states - so as to expand their user-base.

While this might sound speculative at best, we are already seeing glimmers of this new world. For several years, the republic of Estonia has been trying to create a "digital nation for global citizens, ${ }^{25}$ as illustrated by its e-residency program, which provides a government-issued digital ID to all individuals requesting it. Inspired by the notion of government as a platform, ${ }^{26} \mathrm{e}$-Estonia is trying to become the hub for every governmental service, providing all of its electronic residents with a secure identification system, notarisation services, and even the ability to run a company or open a bank account, without ever putting foot into Estonia. With over 28,000 e-residents from all over the world, today, the state of Estonia increasingly operates on a digital layer, enabling people to interact with its governmental platform independently of their country of citizenship or residency. ${ }^{27}$

25 'E-Residency is a new digital nation for global citizens, powered by the Republic of Estonia.' See https://e-resident.gov.ee/

26 O’Reilly, T. (2011), 'Government as a Platform', Innovations 6 (1): 13-40.

27 According to Taavi Kotka, Chief Innovation Officer of Estonia since 2013: 'Countries are like enterprises. They want to increase the wealth of their own people.' Heller, N. (2017), 'Estonia, the Digital Republic', The New Yorker, 18 December, available at https:/www.newyorker.com/magazine/2017/12/18/ estonia-the-digital-republic 


\section{Competing sovereignties}

Competition between nation-states, trying to collect new members by providing more efficient or reliable governments services, has already begun. If Estonia can collect e-residents on a global scale - in spite of its national boundaries - what would prevent virtual nations from doing the same, without a physical territory? Are we actually moving towards a world in which multiple nations are competing to attract more citizens, in the same way as companies are today competing to attract more customers? ${ }^{28}$

Of course, things get murky when we move from purely administrative tasks - like identity, property and company recordation - to more political tasks, involving policy and decision-making. If people could choose to become citizens only of the communities with whom they agree, they would essentially engage in a generalised version of nation-shopping, constantly trying to find the jurisdictions that seem the most advantageous for them. When brought to an extreme, this would ultimately mean the end of politics.

Politics is all about compromises, in order to accommodate different viewpoints without entering into a conflict. An opt-in or exit-based political system essentially eliminates the notion of politics, because it removes the need for compromise. People with different values or opinions would no longer need to argue and deliberate in order to reach consensus, because if they're in disagreement, they can simply leave.

As Bauböck recognises, there are significant challenges in letting people choose which nation they want to pledge allegiance to. The state as a sovereign entity - Hobbes' Leviathan - is not only responsible for preserving the public order, it is also in charge of promoting the general interests, producing common goods and creating a collective sense of redistribution and justice. All these functions could disappear as we move towards a more market-based approach to citizenship.

I am, however, more pessimistic than Bauböck when it comes to the way nation-states will adapt to these technological changes. Given the progressive disengagement of citizens in local politics, and the growing distrust in existing institutions - whose legitimacy is increasingly put into question - it might not be surprising to see a new wave of nationalism emerging all over the world, with nation-states drawing on nationalist and anti-immigration

28 According to its website: 'Bitnation is creating a new world where thousands or millions of nations actually compete for customers by providing better services, instead of using force. It's a world where everyone can choose.' See http://bitnation.co 
narratives to reinforce their hegemony over the territory, essentially redefining on-going relationships between citizens and non-citizens. ${ }^{29}$

At the same time, due to the increasing trends towards globalisation, large internet corporations, like Google or Facebook, are progressively taking on some of the functions that were once specific to the nation-state: from the task of supporting the discourses in the public sphere to their role as identity providers. ${ }^{30}$ With several billions of users on their platforms, these corporations are slowly turning into de facto corporate nations, with their own system of rules that they unilaterally define and impose on their 'citizens'. Traditional nation-states might, therefore, soon have to compete not only with virtual nations, but also with these new transnational corporate nations - similar to Neal Stephenson's franchulates as science-fiction fans will certainly point out. ${ }^{31}$

\section{New opportunities for experimentation}

It is in this convoluted (and daunting) context that I see the rise of blockchainbased virtual nations as a positive omen. Perhaps the reference to virtual nations is not the most accurate one, because the term has a strong political connotation and somewhat gives the impression that these communities are assuming the role of traditional nation-states. While some of these communities do intend to replace the figure of the nation-state (e.g. Bitnation), others are simply trying to experiment with new and allegedly apolitical governance systems, ${ }^{32}$ which nevertheless play a crucial political function.

Because they rely on voluntary association, virtual communities might well remove the need for compromise within a single community, yet they do not eliminate the need for compromise between multiple communities. Hence, politics are not gone, they are simply moving into a different layer. By aggregating people with similar values and opinions, these virtual communities could in fact strengthen the voice of certain minorities - usually stifled by the majority's opinion - and create a more lively debate and political discourse at the outside (rather than on the inside) of these communities. As such, they could end up participating in conventional politics, along with other real-world interests groups.

29 Mitchell, K. (1997), 'Transnational discourse: bringing geography back in', Antipode 29 (2): 101-114.

30 Habermas, J. (1991), The structural transformation of the public sphere: An inquiry into a category of bourgeois society. Cambridge, MA: MIT press.

31 Stephenson, N. (1992), Snow crash. New York: Bantam-Random.

32 Atzori, M. (2015), 'Blockchain technology and decentralized governance: Is the state still necessary?', available at SSRN: https://ssrn.com/ abstract=2709713 or https://doi.org/10.2139/ssrn.2709713 
To conclude, let me take the stance of a beyonder for a moment. As a member of Creative Commons, ${ }^{33}$ I have always been fascinated by its solution. Instead of trying to reform copyright law from the inside or fight it from the outside, Creative Commons introduced an alternative legal regime for creative works that coexists with the existing regulatory framework (in fact, it is based on it) for authors to experiment with new business models that do not rely on the exclusivity and artificial scarcity of copyright law.

Today, with the advent of blockchain technologies, a new wave of innovation is underway in the realm of governance. This innovation is one that will benefit everyone: the insiders, i.e. governmental authorities like Estonia, relying on blockchain technology to increase the transparency and accountability of public administrations; the outsiders, like Peter Thiel, trying to create new self-sovereign nations with the intention to escape from the laws and control of existing nation-states; and, of course, the beyonders, like Bitnation et al., eager to use the technology to support the coordination of transnational communities of voluntary association that operate independently of traditional nation-states, but are capable of peacefully coexisting with them. It is the latter which I am the most excited about, and which I believe could contribute to developing new governance models that might help us build a real global democracy.

Open Access This chapter is licensed under the terms of the Creative Commons Attribution 4.0 International License (http://creativecommons.org/licenses/by/4.0/), which permits use, sharing, adaptation, distribution and reproduction in any medium or format, as long as you give appropriate credit to the original author(s) and the source, provide a link to the Creative Commons license and indicate if changes were made.

The images or other third party material in this chapter are included in the chapter's Creative Commons license, unless indicated otherwise in a credit line to the material. If material is not included in the chapter's Creative Commons license and your intended use is not permitted by statutory regulation or exceeds the permitted use, you will need to obtain permission directly from the copyright holder.

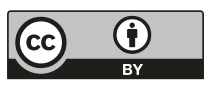

33 Creative Commons is an organisation devoted to expanding the range of artistic, academic, and other content available for people to share and build upon. See http://creativecommons.org 